\title{
TYLOSES AND GUMS: A REVIEW OF STRUCTURE, FUNCTION AND OCCURRENCE OF VESSEL OCCLUSIONS
}

\author{
Veronica De Micco $^{1, *}$, Angela Balzano ${ }^{1}$, Elisabeth A. Wheeler ${ }^{2}$, and Pieter Baas ${ }^{3}$ \\ ${ }^{1}$ Department of Agricultural Sciences, University of Naples Federico II, via Università 100, \\ 80055 Portici (Naples), Italy \\ ${ }^{2}$ Department of Forest Biomaterials, Box 8005, N.C. State University, Raleigh, \\ NC 27695-8005, U.S.A. \\ ${ }^{3}$ Herbarium Division, Naturalis Biodiversity Center, P.O. Box 9517, 2300 RA Leiden, \\ The Netherlands \\ *Corresponding author; e-mail: demicco@unina.it
}

\begin{abstract}
Vessel occlusion through tyloses or gums is a natural phenomenon occurring with aging and heartwood formation, and in sapwood in response to vessel embolism. These types of vessel occlusion play a crucial role to limit the spread of pathogens and wood decay organisms, also as part of compartmentalization after wounding. In the sapwood, they can be considered to be an effective stress response.Here we review the literature on tyloses and gums in hardwoods, starting with the detailed $19^{\text {th }}$ century account on tyloses by Hermine von Reichenbach. The structural diversity of tyloses (from thin-walled to sclerotic) and gum deposits is highlighted and illustrated. Our understanding of the development of vessel occlusions through vessel contact cells of the ray and axial parenchyma has greatly increased over the last decades, also thanks to ultrastructural and immunocytological studies. We critically discuss the postulated relationships between vessel-to-ray parenchyma pit size and vessel size and the incidence of either tyloses or gums and review the occurrence of these types of vessel occlusions in extant and fossil dicots. All factors identified in the literature as stimuli for vessel occlusion probably act through vessel embolism as a single direct trigger. Attempts in the literature to relate vessel occlusion with mechanisms of vessel refilling and embolism repair are controversial and invite more experimental research.
\end{abstract}

Keywords: Compartmentalization, embolism, heartwood, woundwood, protective layer.

\section{INTRODUCTION}

In recent decades, there has been increasing interest in the study of the relationships between functional wood anatomy and environmental factors, especially for forecasting plant responses to climate change and extreme events. Plant survival depends on the ability to harmonise anatomical traits of leaves, stem and root systems, and regulate physiological mechanisms at the whole plant level to allow water flow through the xylem (Holbrook \& Zwieniecki 2005; Kim et al. 2014). 
Each anatomical trait, or combination of traits, plays a role in favouring one or more xylem functions, namely water transport, mechanical stability, biological defence, and storage and mobilisation of metabolites (Beeckman 2016). As a woody plant ages, sapwood (peripheral wood active in water transport) loses its main functions of water flow as well as transport and storage of carbohydrates, and is converted to heartwood (central wood, often dark coloured, no longer active in water flow and carbohydrate transport) whose main functions are decay resistance and mechanical support. The transition from sapwood to heartwood can be gradual or abrupt and is marked by various phenomena including senescence and death of parenchyma as well as vessel occlusion. Conduits that in sapwood serve water flow are unable to do so in the heartwood.

Vessel occlusion can be due to the formation of tyloses or to the deposition of gums. Although a common feature of heartwood, these organic occlusions can also occur in sapwood both normally and after wounding (Gerry 1914; Klein 1923; Murmanis 1975). There is common agreement that the prerequisite for occlusion is cavitation, which would also explain the more frequent tylosis formation in large vessels that are more prone to embolism than narrow ones (Esau 1965; Evert 2006; Kitin \& Funada 2016).

According to the "IAWA list for microscopic features for hardwood identification", deposits in vessels include "tyloses common", "tyloses sclerotic" and "gums and other deposits in heartwood" (IAWA Committee 1989). In the IAWA list, "other deposits in heartwood vessels" include a variety of chemical compounds, which have various colours. According to the subjective criterion "common", these features have only been scored positive in the literature for a minority of all woody species (35\%, Wheeler et al. 2007) and in the InsideWood database (2004-onwards); however, gums or tyloses can occur in the heartwood of virtually all species specifically reviewed for the occurrence of vessel occlusions (Chattaway 1949; Bonsen \& Kučera 1990; Bonsen 1991; Saitoh et al. 1993). Tyloses themselves can contain a wide variety of organic and mineral compounds, including gums, resins, starch, crystals and phenolic compounds.

This review of the literature is focused on tyloses and gums as complementary "functional traits" in tree biology and briefly summarises what we know of their occurrence in extant and fossil woods.

\section{FROM THE FIRST DESCRIPTION OF “SMALL BAGS IN VESSELS” TO THE ULTRASTRUCTURE OF TYLOSES}

Zimmermann (1979) has narrated the discovery of tyloses and their development. Malpighi (1686) in his "Opera Omnia" was the first to report "balloon-shaped sacs" in heartwood vessels. Later on, such structures were named "Thyllen" (tyloses), deriving from the Greek word indicating "bag" or "container", in an anonymous paper in 1845 , which has been ascribed to Hermine, Baroness von Reichenbach of Vienna (Winckler 1854). This Viennese lady observed peculiar structures in vessels that she confidently described as outgrowths of neighbouring wood parenchyma cells passing through the pits, since they always originated close to a region of the vessel wall adjacent to axial or radial parenchyma cells and never in regions where two vessels were in contact (Fig. 1). In the following decades, this view was supported or questioned by several 


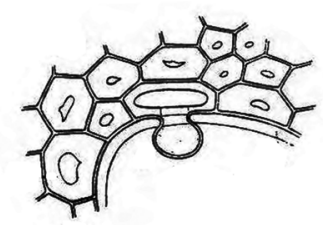

A
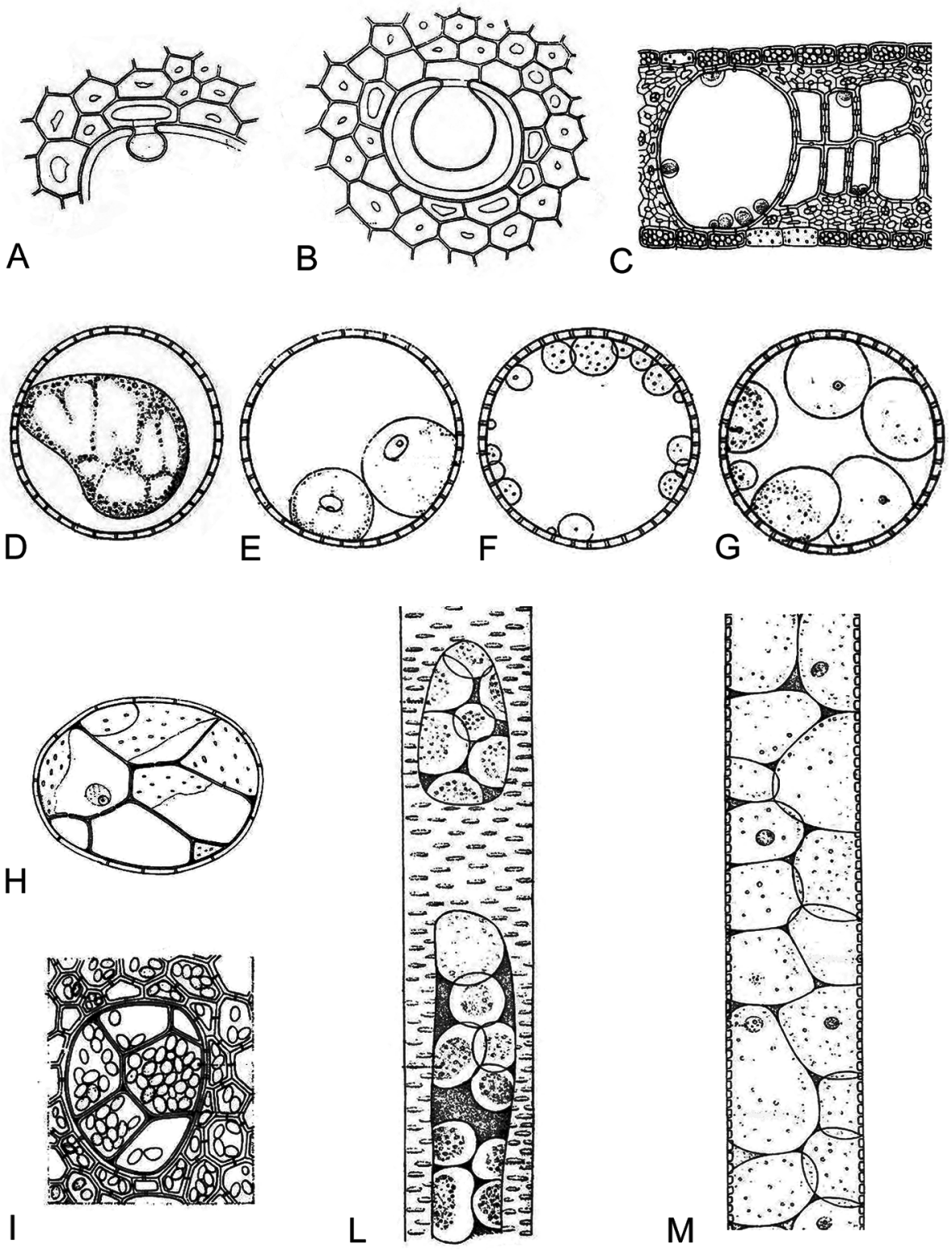

Figure 1. Selection of drawings from the original plates of Reichenbach's paper reported in Zimmermann (1979). - A, B: Bulging tyloses and respective mother cells in a cross section of Vitis vinifera. - C: Young tyloses in vessels of one-year-old shoot of Robinia pseudoacacia.D-G: Vessels of Cucurbita pepo with tyloses with cytoplasmic streaming (D), evident nuclei (E), translucent (young tyloses) or granular (old tyloses) content (F, G) - - H: Vessel of Robinia pseudoacacia filled with many tyloses with evident walls with pits and nuclei. - I: Vessel of Vitis vinifera with tyloses containing starch. - L, M: Vessels of Cucurbita pepo in longitudinal section. 
authors, but Hermine von Reichenbach's views have been generally accepted (Gerry 1914; Koran \& Côté 1965; Esau 1965; Zimmermann 1979; Bonsen \& Kučera 1990; Saitoh et al. 1993; Tyree \& Zimmermann 2002).

Arising mostly from ray cells and to a much lesser extent from axial paratracheal parenchyma cells, tyloses expand into the adjacent vessel through pits (Pearce 1996; Sun et al.2008). Braun (1967) has coined the term "contact cells", synonymous with the "vessel-associated cells" of Czaninski (1977) to indicate parenchyma cells that have the potential to form tyloses or secrete gums into vessels (Catesson \& Moreau 1985; see also Morris \& Jansen 2016). Tyloses are most commonly found in pitted vessels of metaxylem and secondary xylem, and more rarely in protoxylem elements with annular or spiral secondary walls (Zimmermann 1979, citing Hermine von Reichenbach).

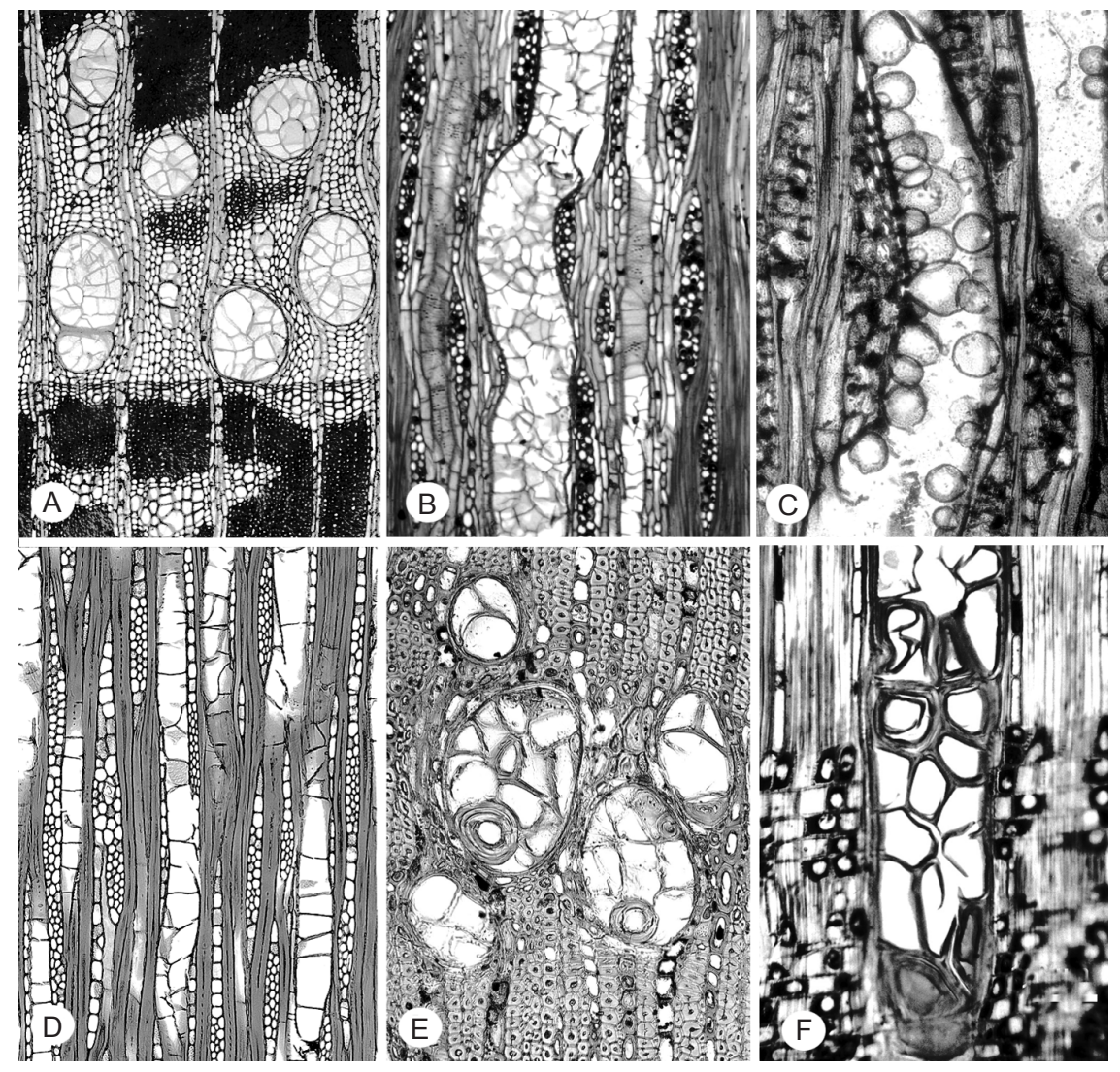

Figure 2. Tyloses, light microscope images. - A, B: Ring-porous wood with tyloses abundant in wide earlywood vessels and less common and less crowded in narrower vessels, Maclura pomifera (Moraceae), photos Els Bakker. - C: Tyloses formation from ray parenchyma in a fossil wood, Cinnamomoxylon oleiferum (Lauraceae), middle Eocene (c. 44 million years). D: Widely spaced tyloses, appearing to segment vessel elements, Altingia excelsa (Altingiaceae). - E: Some tyloses sclerotic, with thick, layered walls. Note: very thick-walled fibres also present, Henriquezia verticillata (Rubiaceae), photo A.M.W. Mennega. - F: Sclerotic tyloses, Pouteria guianensis (Sapotaceae), photo R.B. Miller. 


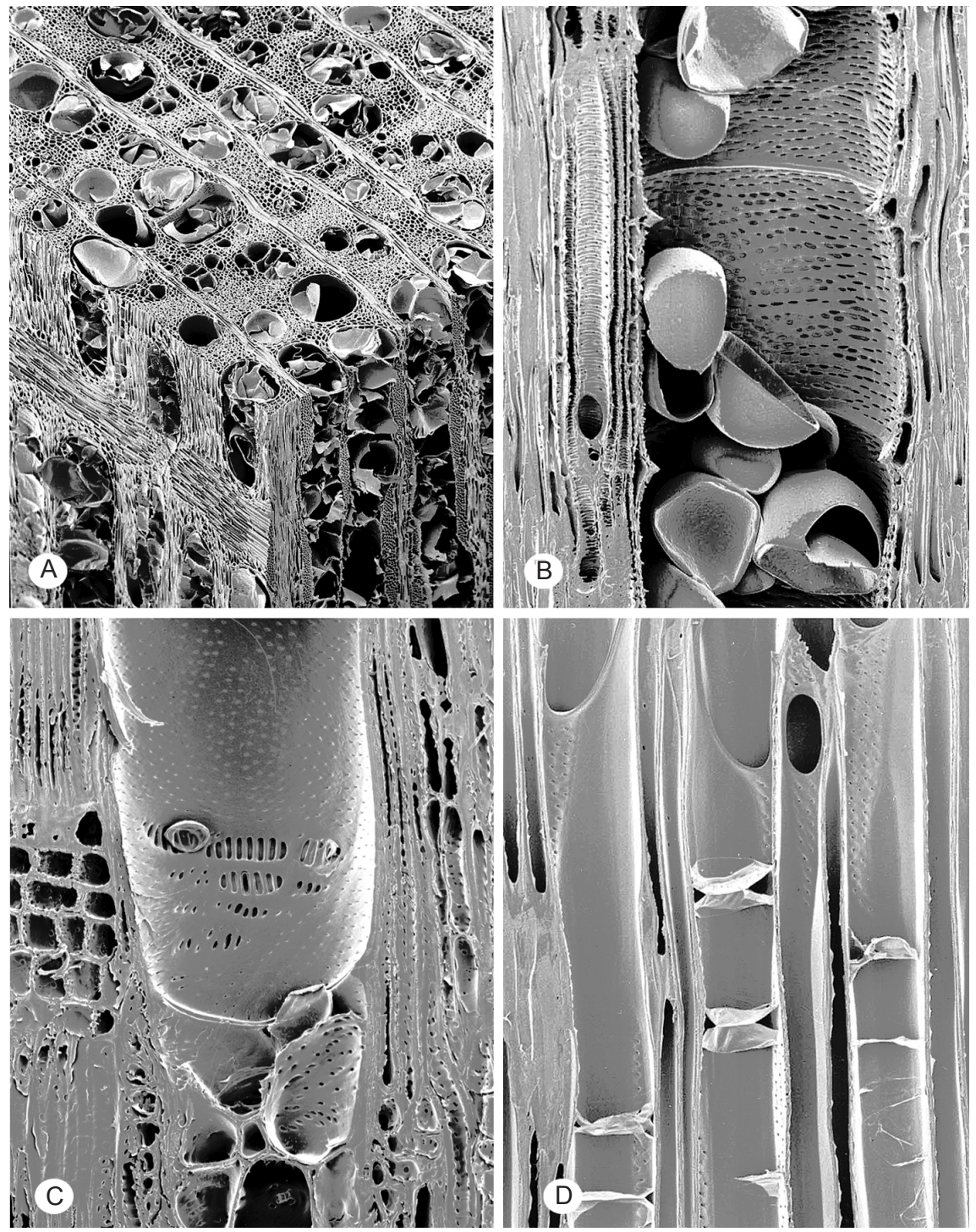

Figure 3. Tyloses, SEM images. - A: Tyloses abundant in wide vessels, Morus australis (Moraceae). - B: Wide vessel with tyloses, narrow vessel without tyloses, Celtis sinensis (Cannabaceae).- C: Tyloses bud emerging from vessel-ray parenchyma pit, Quercus salicina (Fagaceae).D: Septa-like tyloses, Acanthopanax sciadophylloides (Araliaceae). Photos by courtesy of the Forestry and Forest Products Research Institute, Tsukuba, Japan.

Moreover, they can appear as a single tylosis or as groups of tyloses crowded together, as thin- or thick-walled structures, sclerified or unsclerified, pitted or unpitted, and with or without inclusions in the form of starch, crystals, resins, gums, gels or other storage products (Fig. 2 \& 3) (IAWA Committee 1989; Bonsen \& Kučera 1990). The vessel lumen can be partially or completely filled by tyloses. 
Although tyloses typically develop in vessels, they also occur occasionally in tracheids of both softwoods and hardwoods and in the fibres of hardwoods (Chrysler 1908; Gerry 1914; Esau 1965; Gottwald 1972; Peters 1974).

The fine structure of tyloses has been well studied, although in a few species only (Kato \& Kishima 1965; Koran \& Côté 1965; Meyer 1967; Sachs et al. 1970; Shibata et al. 1982; Parameswaran et al.1985; Bonsen 1991). During the formation of a tylosis, the primary wall component of the pit membrane is not merely stretched and pushed into the vessel, but new wall materials, including cellulose, hemicellulose, pectins, suberin and lignin, are actively deposited (Foster 1967; Pearce \& Holloway 1984; Barnett et al. 1993).

In the contact cells, a special layer of pecto-cellulosic composition, called "protective layer" overlies the pit membrane and cell wall portions that are in contact with the vessel (Fig. 4) (Foster 1964; Czaninski 1977; Gregory 1978; Mueller \& Beckman

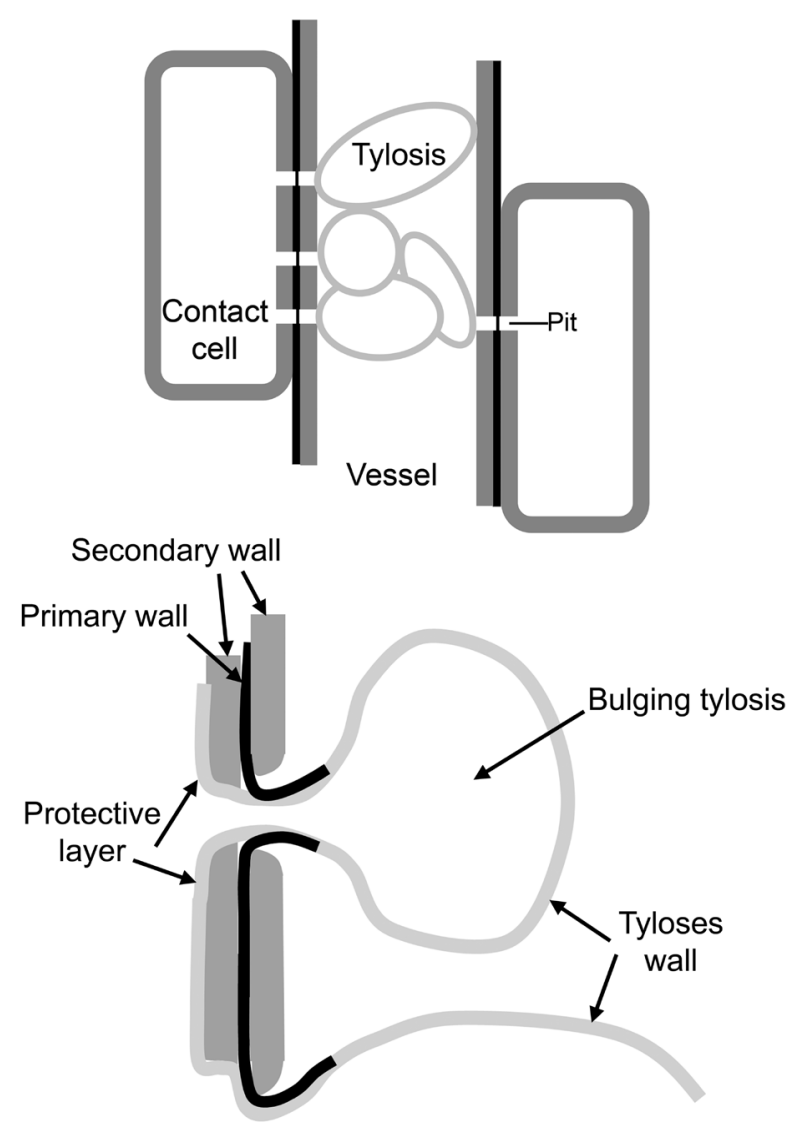

Figure 4. Scheme of bulging tyloses from parenchyma cells to vessel lumen, through pits. The tylosis wall belongs to the protective layer which coats the secondary wall of the contact cell and the primary wall at the pit level before protruding towards the vessel lumen. Overview (above) and detail (below). 
1984; van Bel \& van der Schoot 1988; Evert 2006). The protective layer, also referred to as "tylose-forming layer", "amorphous layer" or "isotropic layer", is firstly deposited between the protoplast and the pit membrane of the vessel-ray parenchyma pits. Then it "balloons" into the vessel lumen giving rise to the tylosis wall (Schmid 1965; Meyer \& Côté 1968; Esau 1977; Fujii et al. 1980, 1981; Schaffer \& Wisniewski 1989).

A budding tylosis is first transparent, while starch grains, a nucleus and nucleolus may appear later in the cytoplasm. Then, ultrastructural changes may occur, including the accumulation of phenolic compounds and crystals in the cytoplasm (Ranjani \& Krishnamurthy 1988; Schmitt \& Liese 1993; Rioux et al. 1998). Tyloses maintain symplastic continuity with the contact cells which are the only cells supplying resources to them since vessels are embolised.

Tyloses can also undergo cell divisions (Schmitt \& Liese 1994). Without obstacles, tyloses can either enlarge up to vessel lumen limits as in Quercus alba, or remain small without completely blocking the vessel as in Kalopanax pictus (Sachs et al. 1970; Sano \& Fukazawa 1991). Different tyloses bulging into the same vessel constrain each other; in narrow vessels, tyloses may misleadingly give the impression of septate vessel elements (e.g. Liquidambar styraciflua, latewood vessels in Robinia pseudoacacia, and Acanthopanax sciadophylloides) (Fig. 3D).

When tylosis expansion is complete, secondary wall formation begins and pit pairs can develop in the zone of contact between tyloses. Tylosis walls have been described as two-layered: the outer layer is amorphous and may be smooth or granular, while the inner surface shows microfibrillar structure which, more than the secondary wall of the contact cell, resembles a thickened primary wall (Foster 1964; Bonsen 1991; Schmitt et al. 1997). The fibrillar layer surrounding the tylosis has also been reported as similar to the compound middle lamella in several species including Pinus balsamifera, Ulmus americana and Quercus rubra (Koran \& Côté 1965; Sachs et al. 1970; MacDonald \& McNabb 1974; Robb et al. 1979; Ouellette 1980; Parameswaran et al. 1985; Bonsen \& Kučera 1990; Rioux et al. 1995). In Eucalyptus, Kalopanax, Quercus, and Robinia, cellulose microfibrils are oriented randomly in the outer layer of the tylosis wall, while they are parallel in the inner layer (Koran \& Côté 1965; Foster 1967; Sachs et al. 1970; Shibata et al. 1982; Parameswaran et al. 1985; Sano \& Fukazawa 1991). At the completion of the tylosis expansion, a multi-layered wall is distinguishable which can be encrusted with suberin or lignin in a sort of secondary wall (Sachs et al. 1970; Ouellette 1980; Obst et al. 1988; Evert 2006). Histochemical tests showed suberised tyloses in Pinus balsamifera and Ulmus americana (Rioux \& Ouellette 1991). Vessels in Fagus, Quercus, and Populus contain suberised tyloses, while those in Betula contain amorphous and fibrillar materials deposited after wounding (Schmitt \& Liese 1990). Multilayered cell wall deposition and lignification of the secondary wall can convert a normal tylosis into a sclereid (sclerified tylosis) (IAWA Committee 1989; Evert 2006). Lignin and suberin make the tylosis wall impermeable, thus constraining water transfer (Dimond 1955; Parameswaran et al. 1985; Schmitt \& Liese 1993; Parke et al. 2007; Collins et al. 2009). Sano \& Fukazawa (1991) found a unique type of tylosis wall in Fraxinus mandshurica var. japonica, poor in microfibrillar cellulose and rich in lignin in the inner sapwood, and collapsing and crumbling in the heartwood. 


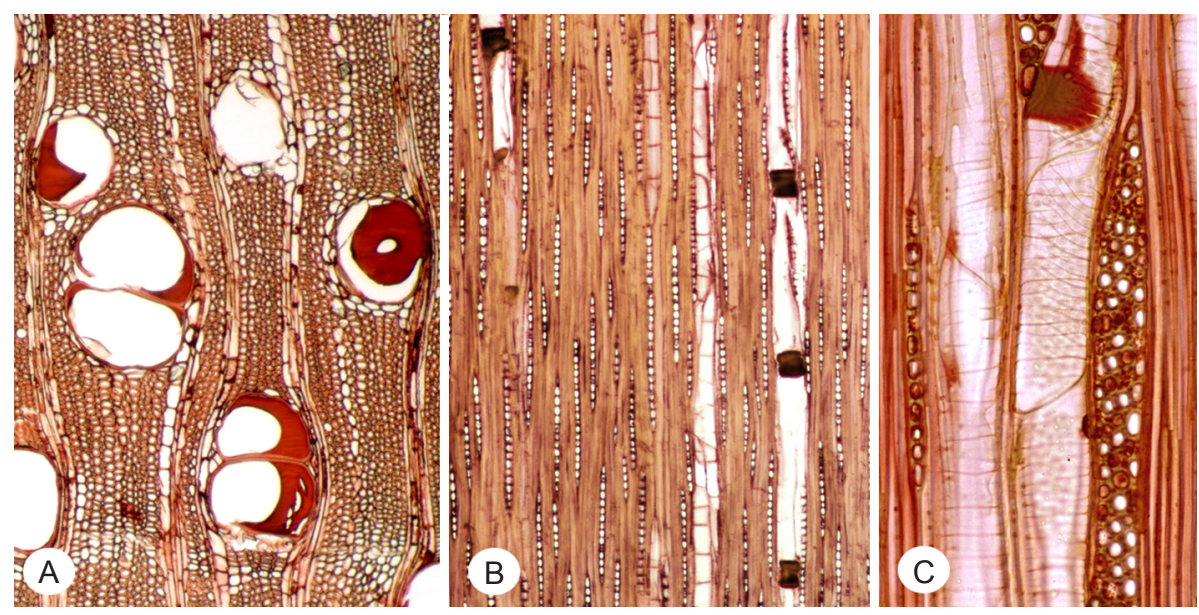

Figure 5. - A: Gum deposits concentrated near vessel-ray contact areas, Khaya senegalensis (Meliaceae), photo Els Bakker. - B: Gum deposits accumulating at perforation plates, Trichilia cipo (Meliaceae), photo Els Bakker. - C: Gums being secreted from ray parenchyma, Prunus serotina (Rosaceae).

\section{GUMS IN VESSELS: WITH AND WITHOUT TYLOSES}

In the literature both "gum" and "gel" have been used to indicate materials occluding vessels, mainly composed of polysaccharides and pectins, thus creating some confusion (Koran \& Yang 1972; Rioux et al. 1998) (Fig. 5). Gums have been reported to form where gels were firstly formed after pathogen-released pectinolytic and cellulolytic enzymes have attacked walls of cells surrounding vessels (Agrios 1969). Here we enter a dichotomy between the anatomical and physiological literature: since gels easily dissolve, they are not normally recorded in anatomical descriptions. Solidified gum deposits (responsible for heartwood colours, and discoloration of woundwood) may well have had unreported gels as their precursors.

Gums have been described as amorphous material occluding vascular tissues or intercellular spaces (Catesson \& Moreau 1985). Hillis (1987) reported that many secondary metabolites stored in vessels have been referred to as gums, although they are not water-soluble compounds as gums are by definition. Currently, the technical term gum is used to indicate a very wide range of secondary metabolites that vary tremendously in their chemistry and can be of chemotaxonomic interest (Hillis 1987).

Like tyloses, gums occluding vessels derive from contact parenchyma cells (Bonsen \& Kučera 1990; Bonsen 1991). Gums in vessels can be either produced by the secretory activity of surrounding living cells (mainly ray cells) and deposited directly into the adjacent vessel lumen or, more rarely, can be secreted by a previously formed tylosis as shown in Eucalyptus blakleyi by Chattaway (1949). Individual tyloses may also be filled with gums (Chattaway 1949). The occlusion of vessels by gums is different from the secretion of gums in ducts. The gums causing vessel occlusion have a different chemical composition from those produced in ducts, which may also contain components originating from the lysis of cells located near the gum canal lumen or from 
cell-wall decomposition (Groom 1926; Rioux et al. 1998; Evert 2006). Based on these considerations, distinguishing between the true gums, mainly made of pectic material occluding vessels, and gums secreted in gum ducts, Rioux et al. (1998) proposed using only the term 'gel' to indicate the pectin occlusions secreted by parenchyma cells into conduits.

Like tyloses, gums have been reported by many authors as occurring both in heartwood and sapwood, either due to natural aging or to factors triggering embolism. The appearance of gums in heartwood has been categorised into four groups: 1) partitions across the vessel lumina, 2) irregular lumps on the inner vessel wall, 3) small droplets on the vessel-parenchyma pits, and 4) thin layers lining the inner vessel wall (Saitoh et al. 1993).

Immunocytochemical studies of Populus basalmifera, Ulmus americana, and Quercus rubra led Rioux et al. (1998) to hypothesise that gum production can be related to tylosis formation. They found that antibodies directed against pectins labelled a material both present at the external layer of the tylosis middle lamella and accumulating outside it, particularly in pit chambers. The same authors suggested a mechanism of secretion of pectic substances across the tylosis primary wall since both the latter and some other compounds within the tylosis were intensely labelled for pectins. Such a mechanism could be similar to that associated with the formation of gums in vessel elements (Rioux et al. 1998).

In gums produced in response to fungal attack, phenolic fungitoxic substances have been reported both filling the tylosis and in the suberised layer (Rioux et al. 1998). Phenolics, anti-feeding deterrents, can be variously located in plant tissues and have been observed also in vessels of young twigs of Rhamnus californica (De Micco \& Aronne 2012).

\section{DO STRUCTURAL LIMITS AFFECT THE TYPE OF VESSEL OCCLUSION?}

Chattaway (1949) reported that the relation between vessel-parenchyma pit size and the type of vessel occlusion was known since the beginning of the 1900s. She noticed that the development of tyloses occurs almost universally in woods with large vesselray pitting (in which the apertures are large and the borders reduced or insignificant), but it rarely or never occurs in woods with small bordered vessel-parenchyma pits (Chattaway 1949). In woods with small bordered vessel-ray pits, the occlusion of the vessels in the heartwood is mainly ascribed to the secretion of gums. After analysing 1100 genera of higher plants, she concluded that whether tyloses or gums are formed is related to the maximum width of the vessel-ray pit apertures: if more than $10 \mu \mathrm{m}$, then tyloses are formed; if less than $10 \mu \mathrm{m}$, then gums are formed. Within the same family, genera with simple pits, whose width exceeds $10 \mu \mathrm{m}$, were characterised by tylosis formation, while those with bordered pits, whose width is lower than $10 \mu \mathrm{m}$, did not form tyloses (Chattaway 1949). Bonsen and Kučera (1990) also analysed the relations between the type of vessel occlusion and the vessel-ray pit aperture diameter in trees and shrubs common in the Swiss flora (both native and introduced) belonging to 65 species from 45 genera and 24 families. Instead of maximum aperture size, they focused on minimum size and established $3 \mu \mathrm{m}$ as the threshold size for occlusion by tyloses 
or by gums. Other authors found similar results (Saitoh et al. 1993; Fujii et al. 2001). Bonsen and Kučera (1990) also found a strong correlation between maximum vessel diameter, which is somewhat related to pit size, and tylosis formation. In the woody flora of Central Europe they studied, species with a maximum vessel diameter greater than $80 \mu \mathrm{m}$ had tyloses, while those with narrower vessels had gum plugs, Magnolia being the only exception of a narrow-vesseled species with tyloses. However, vessel-ray pit apertures over $10 \mu \mathrm{m}$ accompany narrow vessels in Magnolia (InsideWood 2004-onwards). Similarly, the rule associating large-diameter vessels and tylosis occurrence does not apply for many tropical species, e.g., members of the Meliaceae and Fabaceae s.l. which combine wide vessels with narrow pit apertures and gum deposition in the vessels (InsideWood 2004-onwards). Analysing correlations between vessel diameter and presence of tyloses or gums in $>6000$ woody taxa worldwide only very partially supports these generalised trends. In the InsideWood database (2004-onwards; Wheeler 2011), the incidence of the feature "tyloses common" is present in about $17 \%$ of all world woods (Wheeler et al. 2007), and increases from $4 \%$ in very narrow vessel taxa $(<50 / \mu \mathrm{m})$, via $10 \%(50-100 / \mu \mathrm{m})$ and $20 \%(100-200 / \mu \mathrm{m})$ to $25 \%$ in very wide vesseled taxa $(>200 / \mu \mathrm{m})$. However, along this gradient of vessel diameters the incidence of gum deposits also increases from 11, to 13,17 to $24 \%$. These percentages for both types of vessel occlusion are possibly too low, because numerous coded descriptions are probably based on sapwood samples.

\section{VESSEL OCCLUSION AS AGING PHENOMENON OR STRESS RESPONSE}

Vessel occlusion can happen either naturally with xylem aging or in response to various stresses in the sapwood (Chattaway 1949; Ranjani \& Krishnamurthy 1988; Rioux et al. 1995; Dute et al. 1999). Several hypotheses have been suggested to explain the reasons triggering vessel occlusion by tyloses and gums. Whether vessel occlusion is the reason for or the consequence of embolism has been extensively investigated. Hermine von Reichenbach already hypothesised that tylosis formation is not the cause, but the result of the cessation of water conduction (Zimmermann 1979). Her hypothesis was experimentally proven when Klein (1923) observed that tyloses develop when the vessels are air-filled (Zimmermann 1979). Although obvious, it has often been reported that the presence of tyloses affects water movement in living trees and is responsible for a decline in hydraulic conductivity over time (Panshin \& De Zeeuw 1980; Sano \& Fukazawa 1991; Davison 2014). More recently, some authors challenged the longstanding notion that tyloses are induced by embolisms, claiming that vessel embolism is not required for wound-induced tylosis development in grapevine (Sun et al. 2007). Many studies about the relations between embolism and tylosis formation date back to years when cavitation and embolism processes were still poorly understood and the methods used to verify the occurrence of embolism often suffered from artefacts, leading to controversial results (Cochard et al.2000,2010). At present, it is commonly accepted that embolism precedes vessel occlusion (Brodersen et al. 2010). Therefore, all the reasons traditionally claimed for the formation of tyloses and gums can be considered indirect factors primarily responsible for embolism. According to this view, all factors 
causing the interruption of the water column can prime compartmentalization processes culminating in vessel occlusion by tyloses or gums. Biotic and abiotic stresses reported to cause vessel occlusion include: freezing, drought, mechanical wounding (including pruning), flooding, insect attack or pathogen infection (for examples refer to: Chattaway 1949; Dimond 1955; Ouellette 1980; Beckman \& Talboys 1981; Davison \& Tay 1985; Shah \& Babu 1986; van der Molen et al. 1987; Cochard \& Tyree 1990; Schmitt \& Liese 1990, 1994; Pearce 1996; Stevenson et al. 2004; Sun et al. 2008; Davison 2014).

The mechanisms for vessel occlusion are reported to be mediated by hormonal signals. For example, the biosynthesis of ethylene is reported in response to many of the same biotic and abiotic factors triggering tylosis formation (Abeles et al. 1992; Taylor et al. 2002; Saniewski et al.2006), suggesting that ethylene could be a coordinating factor in the development of such occlusions (Sun et al. 2007; McElrone et al. 2010). Auxin is also reported to induce tylosis formation, probably through the stimulation of ethylene production (Abeles \& Rubinstein 1964; Lieberman 1979; Yu \& Yang 1979).

Embolism-related tylosis formation is considered as a quick response to stressful conditions and explains why tyloses are frequent in vessels close to wounds or around sites of pathogen inoculation, and in large vessels of the earlywood that are most vulnerable to embolism (Ellmore \& Ewers 1985; Cochard \& Tyree 1990; Pearce 1991; Hargrave et al. 1994; Davis et al. 1999). In the case of biotic infections, vessel occlusion by tyloses or gums plays an important role in slowing down and preventing the spread of pathogens, embolism and in reducing water loss in non-functional xylem; thus vessel blockage can be considered an example of active disease resistance. The success of vessel-blocking as a barrier against pathogens depends on the speed of tylosis initiation and growth, on the presence of suberised walls and, also in the case of gumocclusions, on possible accumulation of anti-microbial compounds such as tannins, catechol, flavonoids and coumarins that prevent spreading of pathogens in the infected part of the plant (Del Rio et al. 2001). When tylosis formation is the main mechanism for vessel occlusion to impede fungal colonisation, the suberisation of tylosis walls is common and facilitates sealing of vessels, while gummosis is generally not accompanied by suberisation processes even in species showing a strong compartmentalization wall 4 barrier zone according to the CODIT model (Shigo \& Marx 1977; Pearce \& Woodward 1986; Bonsen \& Kučera 1990; Pearce 1990).

During tylosis formation, in defence mechanisms against vascular pathogens, the protective layer seems to have an active role in so far as it represents a protection layer formed by the living cell as a defence against the adjacent dead cell element (Meyer 1967; Meyer \& Côté 1968; Mueller \& Beckman 1984). Moreover, it could also be involved in solute exchange and act as sugar buffer against oscillations in the hydrostatic pressure in the vessels (van Bel \& van der Schoot 1988). It has been suggested that the fibrillar pecto-cellulosic protective layer allows much easier solute access to the symplast as compared with lignified walls (Gregory 1978; van Bel \& van der Schoot 1988). Moreover, the contact cells themselves seem to be involved in the metabolically controlled release of sucrose into unoccluded vessels (Sauter et al. 1973).

According to some authors, tylosis formation or gel/gum depositions might have a role in embolism repair by contributing to osmotic-related mechanisms for refilling 
of embolised vessels (Canny 1997; Crews et al.2003; Brodersen et al. 2010; Cochard et al.2010). However, in this review, we refrain from entering the controversial debate on the role of tyloses and gums in vessel refilling.

\section{OCCURRENCE IN MODERN AND FOSSIL WOODS}

It is well known that tyloses form in both ring-porous (e.g. Castanea, Fraxinus, Juglans, Ulmus, Robinia, and Quercus) and diffuse-porous woods (e.g. Fagus, Populus, and Salix). Tyloses in heartwood vessels were reported by Malpighi in 1686. It was only much later that Gerry (1914) described tyloses in sapwood. Klein (1923) showed that tyloses could be produced artificially in sapwood as the consequence of embolism after wounding. In some genera (e.g. Quercus, Robinia, and Castanea), tyloses form naturally in heartwood and sapwood. Genera, such as Acer and Swietenia, which are not able to form tyloses, form instead other types of vessel plugs, referred to as gum deposits (Chattaway 1949; Bauch et al. 1980; Saitoh et al. 1993).

A survey on the occurrence of tyloses and secretion of gums in the wood of over 1,100 genera was made by Chattaway (1949). Since this first extensive study, several authors have reported tyloses in many species, grouping information at the genus and family levels. Saitoh et al. (1993) studied tyloses in sapwood and heartwood in 50 Japanese hardwoods and found their occurrence in the middle sapwood, near the transitional region from sapwood to heartwood, or in the inner regions of the wood in species lacking heartwood.

Like tyloses, gums may occur in both ring-porous (e.g. Zelkova, Phellodendron, and Maackia) and diffuse-porous woods (e.g. Betula, Prunus, and Tilia) (Koran \& Yang 1972; Schmitt \& Liese 1990).

A search of the InsideWood modern wood database (2004-onwards; Wheeler 2011) indicates that "common tyloses" occur in 111 families and sub-families, "sclerotic tyloses" in 27 and "gums or other occlusions" in 106. Table 1 and Table 2 respectively list the families having tyloses and gums commonly occurring; 19 out of 111 families having "common tyloses" also have the other two types of occlusions. "Common tyloses" are present in $17 \%$ of world woods, with much higher percentages in India and Australia, and very low values in the Mediterranean basin, temperate Europe and New Zealand. Gums and other deposits in vessels are present in $18 \%$ of world woods, with high percentages in the Mediterranean basin, India, Australia and Tropical Africa.

The fossil record shows that the production of these protrusions has been a common process in woody plants since at least the late Paleozoic. The earliest reports of tyloses in fossil plants are from the Carboniferous, and include a progymnosperm Protopitys buchiana (Scheckler \& Galtier 2003) and several ferns (Williamson 1876; Weiss 1906; Phillips \& Galtier 2005). Tyloses or tylosis-like structures have also been described in the Triassic gymnosperm wood, Protocedroxylon mineense, in the Permian fossil wood of Shenoxylon mirabile, in the Jurassic woods Metacedroxylon scoticum Holden and Xenoxylon morrisonense Medlyn \& Tidwell, and in some Cretaceous and Cenozoic permineralized angiosperm woods (for examples, refer to: Jeffrey 1904; Holden 1915; Bailey 1924; Medlyn \& Tidwell 1975; Manchester 1983; Takahashi \& Suzuki 2003; 
Table 1. List of Families in which common and sclerotic tyloses occur as reported in the Modern Woods in the InsideWood database (August 2015) (InsideWood 2004-onwards; Wheeler 2011).

Tyloses in Modern Woods

\begin{tabular}{|c|c|c|c|}
\hline \multicolumn{3}{|c|}{ "Normal" tyloses common } & \multirow{2}{*}{$\begin{array}{l}\quad \begin{array}{c}\text { Tyloses sclerotic } \\
\text { (in very few species only) }\end{array} \\
\text { Achariaceae }\end{array}$} \\
\hline Achariaceae & Euphorbiaceae & Myrtaceae & \\
\hline Adoxaceae & Eupteleaceae & Nothofagaceae & Anacardiaceae \\
\hline Anacardiaceae & Fagaceae & Nyctaginaceae & Bonnetiaceae \\
\hline Apocynaceae & Gentianaceae & Ochnaceae & Calophyllaceae \\
\hline Araliaceae & Hamamelidaceae & Olacaceae & Cannabaceae \\
\hline Asteropeiaceae & Hernandiaceae & Oleaceae & Celastraceae \\
\hline Barbeyaceae & Humiriaceae & Onagraceae & Chrysobalanaceae \\
\hline Begoniaceae & Hydrangeaceae & Oxalidaceae & Connaraceae \\
\hline Bignoniaceae & Hypericaceae & Pandaceae & Convolvulaceae \\
\hline Bixaceae & Icacinaceae & Passifloraceae & Dipterocarpaceae \\
\hline Bonnetiaceae & Irvingiaceae & Paulowniaceae & Euphorbiaceae \\
\hline Boraginaceae & Ixonanthaceae & Pentaphylacaceae & Hydrangeaceae \\
\hline Brunelliaceae & Juglandaceae & Peraceae & Icacinaceae \\
\hline Burseraceae & Kirkiaceae & Phyllanthaceae & Irvingiaceae \\
\hline Calophyllaceae & Lamiaceae & Picrodendraceae & Ixonanthaceae \\
\hline Calycanthaceae & Lauraceae & Piperaceae & Lauraceae \\
\hline Cannabaceae & Lecythidaceae & Platanaceae & Lecythidaceae \\
\hline Capparaceae & Leguminosae Caesalpinioideae & Rhamnaceae & Leguminosae Papilionoideae \\
\hline Caryocaraceae & Leguminosae Papilionoideae & Rhizophoraceae & Melastomataceae \\
\hline Casuarinaceae & Linaceae & Rhoipteleaceae & Monimiaceae \\
\hline Celastraceae & Loganiaceae & Rosaceae & Moraceae \\
\hline Centroplacaceae & Lythraceae & Rubiaceae & Myristicaceae \\
\hline Cercidiphyllaceae & Magnoliaceae & Rutaceae & Olacaceae \\
\hline Chrysobalanaceae & Malpighiaceae & Salicaceae & Peraceae \\
\hline Clusiaceae & Malvaceae Bombacoideae & Santalaceae & Rubiaceae \\
\hline Combretaceae & Malvaceae Brownlowioideae & Sapotaceae & Sapotaceae \\
\hline Connaraceae & Malvaceae Byttnerioideae & Sarcolaenaceae & Stemonuraceae \\
\hline Convolvulaceae & Malvaceae Dombeyoideae & Solanaceae & \\
\hline Cornaceae & Malvaceae Grewioideae & Stemonuraceae & \\
\hline Cunoniaceae & Malvaceae Helicteroideae & Theaceae & \\
\hline Daphniphyllaceae & Malvaceae Sterculioideae & Torricelliaceae & \\
\hline Didiereaceae & Melastomataceae & Ulmaceae & \\
\hline Dipterocarpaceae & Monimiaceae & Urticaceae & \\
\hline Elaeagnaceae & Moraceae & Verbenaceae & \\
\hline Elaeocarpaceae & Moringaceae & Violaceae & \\
\hline Ericaceae & Myoporaceae & Vitaceae & \\
\hline Erythroxylaceae & Myristicaceae & Vochysiaceae & \\
\hline
\end{tabular}


Table 2. List of Families in which gums and other organic occlusions commonly occur as reported in the Modern Woods in the InsideWood database (August 2015) (InsideWood 2004-onwards; Wheeler 2011).

\begin{tabular}{|c|c|c|}
\hline \multicolumn{3}{|c|}{ Gums and other deposits common in Modern Woods } \\
\hline Acanthaceae & Euphorbiaceae & Nyctaginaceae \\
\hline Achariaceae & Goodeniaceae & Ochnaceae \\
\hline Anacardiaceae & Goupiaceae & Olacaceae \\
\hline Anisophylleaceae & Himantandraceae & Peraceae \\
\hline Annonaceae & Huaceae & Phyllanthaceae \\
\hline Aphloiaceae & Humiriaceae & Picramniaceae \\
\hline Apocynaceae & Hypericaceae & Picrodendraceae \\
\hline Asteraceae & Icacinaceae & Polygalaceae \\
\hline Betulaceae & Juglandaceae & Proteaceae \\
\hline Bignoniaceae & Koeberliniaceae & Putranjavaceae \\
\hline Boraginaceae & Lamiaceae & Quiinaceae \\
\hline Burseraceae & Lauraceae & Resedaceae \\
\hline Buxaceae & Lecythidaceae & Rhamnaceae \\
\hline Calophyllaceae & Leguminosae Caesalpinioideae & Rhizophoraceae \\
\hline Canellaceae & Leguminosae Mimosoideae & Rosaceae \\
\hline Cannabaceae & Leguminosae Papilionoideae & Rubiaceae \\
\hline Capparaceae & Loganiaceae & Rutaceae \\
\hline Cardiopteridaceae & Lythraceae & Salicaceae \\
\hline Caryocaraceae & Magnoliaceae & Salvadoraceae \\
\hline Casuarinaceae & Malpighiaceae & Santalaceae \\
\hline Celastraceae & Malvaceae Bombacoideae & Sapindaceae \\
\hline Chenopodiaceae & Malvaceae Brownlowioideae & Sapotaceae \\
\hline Cistaceae & Malvaceae Byttnerioideae & Sarcobataceae \\
\hline Clusiaceae & Malvaceae Dombeyoideae & Simaroubaceae \\
\hline Combretaceae & Malvaceae Grewioideae & Styracaceae \\
\hline Convolvulaceae & Malvaceae Helicteroideae & Surianaceae \\
\hline Ctenolophonaceae & Malvaceae Malvoideae & Tamaricaceae \\
\hline Cunoniaceae & Malvaceae Sterculioideae & Tetrameristaceae \\
\hline Dilleniaceae & Melastomataceae & Thymelaeaceae \\
\hline Dipterocarpaceae & Meliaceae & Ulmaceae \\
\hline Ebenaceae & Moraceae & Urticaceae \\
\hline Elaeagnaceae & Myricaceae & Verbenaceae \\
\hline Elaeocarpaceae & Myristicaceae & Vochysiaceae \\
\hline Ericaceae & Myrtaceae & Zygophyllacea \\
\hline Escalloniaceae & Nitrariaceae & \\
\hline Eucommiaceae & Nothofagaceae & \\
\hline
\end{tabular}


InsideWood 2004-onwards; Feng et al. 2010; Boonchai et al. 2015). The earliest large angiosperm tree, Paraphyllanthoxylon, has abundant tyloses (Bailey 1924; Wheeler \& Lehman 2009). Of the 1,800 records of fossil angiosperm woods in InsideWood (2004-onwards; Wheeler 2011), "common tyloses" occur in over 500 records from 64 families and sub-families plus other woods (mostly Cretaceous in age) whose familial affinities are not known. The apparently more common occurrence of tyloses in fossil woods (30\%) is because, unless fossil wood descriptions specifically stated that tyloses were rare, the phrase "tyloses present" was recorded as IAWA feature 56 "tyloses common".

In this review, we have not included tyloses and gums in woody monocots such as palms, but they certainly occur there, especially in metaxylem vessels in leaf traces in the stem prior to leaf shedding (Tomlinson et al. 2011; Tomlinson, personal communication 2016).

\section{CONCLUSIONS}

Since the first reports on the occurrence of tyloses or gums in vessels, numerous studies have been conducted in which many different causes triggering vessel occlusion have been considered. In many studies, the understanding of either tylosis formation or gum deposition was not the main goal, and different approaches and methods have been used sometimes leading to contrasting opinions. The development of more and more sophisticated methods and instruments have unambiguously demonstrated that vessel occlusion is a consequence of cavitation, thus all causes claimed for vessel occlusion primarily trigger embolism. The questions whether tyloses and gums in vessels always lead to permanent vessel occlusion or whether partially occluded vessels can refill remain to be answered. The formation of tyloses is considered an irreversible occlusion of conduits because, as cellular structures, they would require a very complex process to be degraded. Whether gums can be dissolved and serve as osmoticum probably depends on "their stage of development". Precursory gels (Crews et al. 2003) might be dissolved in refilling vessels; for more or less solid gums in discoloured woundwood this is almost impossible to envision, but further experimental studies are needed.

\section{ACKNOWLEDGEMENTS}

This study profited from discussions within the COST Action STReESS (COST-FP1106). The permission to use images of the FFPRI website (Fig. 3), and from InsideWood (Fig. 2 and 5) is gratefully acknowledged.

\section{REFERENCES}

Abeles FB, Morgan PW \& Saltveit ME Jr. 1992. Ethylene in plant biology. Academic Press Inc., San Diego.

Abeles FB \& Rubinstein B. 1964. Regulation of ethylene evolution and leaf abscission by auxin. Plant Physiol. 39: 963-969.

Agrios G. 1969. Plant pathology. Academic Press Inc., New York.

Bailey IW. 1924. The problem of identifying the wood of Cretaceous and later dicotyledons: Paraphyllanthoxylon arizonense. Ann. Bot. 38: 439-451. 
Barnett JR, Cooper P \& Bonner LJ. 1993. The protective layer as an extension of the apoplast. IAWA J. 14: 163-171.

Bauch J, Shigo AL \& Starck M. 1980. Wound effects in the xylem of Acer and Betula species. Holzforschung 34: 153-160.

Beckman CH \& Talboys PW. 1981. Anatomy of resistance. In: Mace ME, Bell AA \& Beckman CH (eds.), Fungal wilt diseases of plants: 487-521. Academic Press, London.

Beeckman H. 2016. Wood anatomy and trait-based ecology. IAWA J. 37: 127-151.

Bonsen KJ. 1991. Gefäßverschluß-Mechanismen in Laubbäumen.Vierteljahrsschrift der Naturforschenden Gesellschaft in Zürich 136: 13-50.

Bonsen KJ \& Kučera LJ. 1990. Vessel occlusions in plants: morphological, functional and evolutionary aspects. IAWA J. 11: 393-399.

Boonchai N, Manchester SR \& Wheeler EA.2015. Welkoetoxylon multiseriatum: fossil moraceous wood from the Eocene Green River Formation, Wyoming, U.S.A. IAWA J. 36: 158-166.

Braun HJ. 1967. Development and structure of wood rays in view of contact-isolation-differentiation to hydrosystem. Holzforschung 21: 33-37.

Brodersen CR, McElrone AJ, Choat B, Matthews MA \& Shackel KA. 2010. The dynamics of embolism repair in xylem: in vivo visualizations using high resolution computed tomography. Plant Physiol. 154: 1088-1095.

Canny M. 1997. Tyloses and maintenance of transpiration. Ann. Bot. 80: 565-570.

Catesson AM \& Moreau M. 1985. Secretory activity in vessel contact cells. Israel J. Bot. 34: $157-165$.

Chattaway MM. 1949. The development of tyloses and secretion of gum in heartwood formation. Aust. J. Biol. Sci. 2: 227-240.

Chrysler MA. 1908. Tyloses in tracheids of conifers. New Phytol. 7: 198-204.

Cochard H \& Tyree MT. 1990. Xylem dysfunction in Quercus: vessel sizes, tyloses, cavitation and seasonal changes in embolism. Tree Physiol. 6: 393-407.

Cochard H, Bodet C, Améglio T \& Cruiziat P. 2000. Cryo-scanning electronmicroscopy observations of vessel content during transpiration in walnut petioles: facts or artifacts? Plant Physiol. 124: 1191-1202.

Cochard H, Herbette S, Barigah T, Badel E, Ennajeh M \& Vilagrosa A. 2010. Does sample length influence the shape of xylem embolism vulnerability curves? A test with the Cavitron spinning technique. Plant Cell Environ. 33: 1543-1552.

Collins BR, Parke JL, Lachenbruch B \& Hansen EM. 2009. The effects of Phytophthora ramorum infection on the hydraulic conductivity and tylosis formation in tanoak sapwood. Can. J. For. Res. 39: 1766-1776.

Crews LJ, McCully ME \& Canny MJ. 2003. Mucilage production by wounded xylem tissue of maize roots - Time course and stimulus. Func. Plant Biol. 30: 755-766.

Czaninski Y. 1977. Vessel-associated cells. IAWA Bull. 1977/3: 51-55.

Davis SD, Sperry JS \& Hacke EG. 1999. The relationship between xylem conduit diameter and cavitation caused by freezing. Ann. Bot. 86: 1367-1372.

Davison EM. 2014. Resolving confusions about jarrah dieback - don't forget the plants. Australas. Plant Pathol. 43: 691-701.

Davison EM \& Tay FCS. 1985. The effect of waterlogging on seedlings of Eucalyptus marginata. New Phytol. 101: 743-754.

Del Rio JA, Gonzales A, Fuster MD, Botia JM, Gomez P, Frias P \& Ortunio A. 2001. Tylose formation and changes in phenolic compounds of grape roots infected with Phaemoniella chlamydospora and Phaeoacremonium species. Phytopathol. Mediterr. 40: 394-399.

De Micco V \& Aronne G. 2012. Anatomy and lignin characterization of twigs in the chaparral shrub Rhamnus californica. IAWA J. 33: 151-162. 
Dimond AE. 1955. Pathogenesis in the wilt diseases. Ann. Rev. Plant Physiol. 6: 329-350.

Dute RR, Duncan KM \& Duke B. 1999. Tyloses in abscission scars of loblolly pine. IAWA J. 20: 67-74.

Ellmore GS \& Ewers FW. 1985. Hydraulic conductivity in trunk xylem of elm, Ulmus americana. IAWA J. 6: 303-307.

Esau K. 1965. Plant anatomy. McGraw-Hill, New York.

Esau K. 1977. Anatomy of seed plants. John Wiley \& Sons, Inc., New York.

Evert RF. 2006. Esau's plant anatomy: meristems, cells, and tissues of the plant body: their structure, function, and development. John Wiley \& Sons, Inc., Hoboken, New Jersey.

Feng Z, Wang J, Rossler R, Kerp H \& Wei HB. 2013. Complete tylosis formation in a latest Permian conifer stem. Ann. Bot. 6: 1075-1081.

Foster RC. 1964. Fine structure of tyloses. Nature 204: 494-495.

Foster RC. 1967. Fine structure of tyloses in three species of the Myrtaceae. Aust. J. Bot. 1: $25-34$.

Fujii T, Harada H \& Saiki H. 1980. The layered structure of secondary walls in axial parenchyma of the wood of 51 Japanese angiosperm species. Mokuzai Gakkaishi 26: 373-380.

Fujii T, Harada H \& Saiki H. 1981. Ultrastructure of "amorphous layer" in xylem parenchyma cell wall of angiosperm species. Mokuzai Gakkaishi 27: 149-156.

Fujii T, Lee SJ, Kuroda N \& Suzuki Y. 2001. Conductive function of intervessel pits through a growth ring boundary of Machilus thunbergii. IAWA J. 22: 1-14.

Gerry E. 1914. Tyloses; their occurrence and practical significance in some American woods. J. Agric. Res. 1: 445-469.

Gottwald HP. 1972. Tyloses in fibre tracheids. Wood Sci. Technol. 6: 121-127.

Gregory RA. 1978. Living elements of the conducting secondary xylem of sugar maple (Acer saccharum Marsh.). IAWA Bull. 4: 65-69.

Groom P. 1926. Excretory systems in the secondary xylem of Meliaceae. Ann. Bot. 3: 631649.

Hargrave KR, Kolb KJ, Ewers FW \& Davis SD. 1994. Conduit diameter and drought-induced embolism in Salvia mellifera Greene (Labiatae). New Phytol. 695-705.

Hillis WE. 1987. Heartwood and tree exudates. Springer-Verlag, Berlin.

Holbrook NM \& Zwieniecki MA. 2005. Vascular transport in plants. Elsevier Academic Press, Amsterdam.

Holden R. 1915. A Jurassic wood from Scotland. New Phytol. 14 : 205-209.

IAWA Committee. 1989. IAWA list of microscopic features for hardwood identification. IAWA Bull. n.s. 10: 219-332.

InsideWood. 2004-onwards. http://insidewood.lib.ncsu.edu [Accessed 11 November 2015].

Jeffrey EC. 1904. A fossil Sequoia from the Sierra Nevada. Bot. Gaz. 321-332.

Kato H \& Kishima T. 1965. Some morphological observations of tyloses. Wood Res. 6: $55-60$.

Kim HK, Park J \& Hwang I. 2014. Investigating water transport through the xylem network in vascular plants. J. Exp. Bot. 65: 1895-1904.

Kitin P \& Funada R. 2016. Earlywood vessels in ring-porous trees become functional for water transport after bud burst and before the maturation of the current-year leaves. IAWA J. 37: $315-331$.

Klein G. 1923. Zur Ätiologie der Thyllen. Z. Bot. 15: 417-39.

Koran Z \& Côté WA. 1965. The ultrastructure of tyloses. In: Côté WA(ed.), Cellular ultrastructure of woody plants: 319-333. Syracuse University Press, Syracuse.

Koran Z \& Yang KC. 1972. Gum distribution in yellow birch. Wood Sci. 5: 95-101.

Lieberman M. 1979. Biosynthesis and action of ethylene. Annu. Rev. Plant Physiol. 30: $533-591$. 
MacDonald WL \& McNabb HS. 1974. Electron microscope observations of Ceratocystis ulmiinduced tylosis development in Ulmus. Eur. J. Forest Pathol. 4: 2-10.

Malpighi M. Opera omnia. London, 1686-87; Leida, 1987. Cited by: Belloni L. (ed.), Opere scelte di Marcello Malphighi: 75-99. Tipografia Torinese SpA, Torino.

Manchester SR. 1983. Fossil wood of the Engelhardieae (Juglandaceae) from the Eocene of North America: Engelhardioxylon. Bot. Gaz. 144 : 157-163.

McElrone AJ, Grant JA \& Kluepfel DA. 2010. The role of tyloses in crown hydraulic failure of mature walnut trees afflicted by apoplexy disorder. Tree Physiol. 30: 761-772.

Medlyn DA \& Tidwell WD. 1975. Conifer wood from the Upper Jurassic of Utah. Part I. Xenoxylon morrisonense sp. nov. Amer. J. Bot. 62: 203-208.

Meyer RW. 1967. Tyloses development in white oak. For. Prod. J. 17: 50-57.

Meyer RW \& Côté Jr WA. 1968. Formation of the protective layer and its role in tylosis development. Wood Sci. Technol. 2: 84-94.

Morris H \& Jansen S. 2016. Secondary xylem parenchyma - from classical terminology to functional traits. IAWA J. 37: 1-15.

Mueller WC \& Beckman CK. 1984. Ultrastructure of the cell wall of vessel contact cells in the xylem of tomato sterns. Ann. Bot. 53: 107-114.

Murmanis L. 1975. Formation of tyloses in felled Quercus rubra L. Wood Sci. Technol. 9: $3-14$.

Obst JR, Sachs IB \& Kuster TA. 1988. The quantity and type of lignin in tyloses of bur oak (Quercus macrocarpa). Holzforschung 42: 229-231.

Ouellette GB. 1980. Occurrence of tyloses and their ultrastructural differentiation from similarly configured structures in American elm infected by Ceratocystis ulmi. Can. J. Bot. 58: $1056-1073$.

Panshin AJ \& DeZeeuw CD. 1980. Textbook of wood technology. McGraw-Hill, New York.

Parameswaran N, Knigge H \& Liese W. 1985. Electron microscopic demonstration of a suberized layer in the tylosis wall of beech Fagus sylvatica and oak Quercus robur. IAWA Bull. n.s. 6: $269-271$.

Parke JL, Oh E, Voelker S, Hansen EM, Buckles G \& Lachenbruch B. 2007. Phytophthora ramorum colonizes tanoak xylem and is associated with reduced stem water transport. Phytopathol. 97: 1558-1567.

Pearce RB. 1990. Occurrence of decay-associated xylem suberization in a range of wood species. Eur. J. Forest Pathol. 20: 275-289.

Pearce RB. 1991. Reaction zone relics and the dynamics of fungal spread in the xylem of woody angiosperms. Physiol. Mol. Plant Pathol. 1: 41-55.

Pearce RB. 1996. Antimicrobial defences in the wood of living trees. New Phytol. 132: 203-233.

Pearce RB \& Holloway PJ. 1984. Suberin in the sapwood of oak (Quercus robur L.): its composition from a compartmentalization barrier and its occurrence in tyloses in undecayed wood. Physiol. Plant Pathol. 24: 71-81.

Pearce RB \& Woodward S. 1986. Compartmentalization and reaction zone barriers at the margin of decayed sapwood in Acer saccharinum L. Physiol. Mol. Plant Pathol. 29: 197-216.

Peters WJ. 1974. Tylosis formation in Pinus tracheids. Bot. Gaz. 135: 126-131.

Phillips TL \& Galtier J. 2005. Evolutionary and ecological perspectives of Late Paleozoic ferns: Part I. Zygopteridales. Rev. Palaeobot. Palynol. 3: 165-203.

Ranjani K \& Krishnamurthy KV. 1988. Nature of vestures in the vestured pits of some Caesalpiniaceae. IAWA J. 9: 31-33.

Rioux D, Chamberland H, Simard M \& Ouellette GB. 1995. Suberized tyloses in trees: An ultrastructural and cytochemical study. Planta 196: 125-140. 
Rioux D, Nicole M, Simard M \& Ouellette GB. 1998. Immunocytochemical evidence that secretion of pectin occurs during gel (gum) and tylosis formation in trees. Phytopathol. 6: 494-505.

Rioux D \& Ouellette GB. 1991. Barrier zone formation in host and nonhost trees inoculated with Ophiostoma ulmi. I. Anatomy and histochemistry. Can. J. Bot. 69: 2055-2073.

Robb J, Brisson JD, Busch L \& Lu BC. 1979. Ultrastructure of wilt syndrome caused by Verticillium dahliae. VII. Correlated light and transmission electron microscope identification of vessel coatings and tyloses. Can. J. Bot. 57: 822-834.

Sachs I, Kuntz J, Ward J, Nair G \& Schultz N. 1970. Tyloses structure. Wood and Fiber 2: 259-268.

Saitoh T, Ohtani J \& Fukazawa K. 1993. The occurrence and morphology of tyloses and gums in the vessels of Japanese hardwoods. IAWA J. 14: 359-371.

Saniewski M, Ueda J, Miyamoto K, Horbowicz M \& Puchalski J. 2006. Hormonal control of gummosis in Rosaceae. J. Fruit Ornam. Plant Res. 14 (Suppl. 1): 137-144.

Sano Y \& Fukazawa K. 1991. Structural differences of tyloses in Fraxinus mandshurica var. japonica and Kalopanax pictus. IAWA J. 12: 241-249.

Sauter JJ, Iten W \& Zimmermann MH. 1973. Studies on the release of sugar into the vessels of sugar maple (Acer saccharum). Can. J. Bot. 51: 1-8.

Schaffer K \& Wisniewski M. 1989. Development of the amorphous layer (protective layer) in xylem parenchyma of cv. Golden Delicious apple, cv. Loring Peach, and willow. Amer. J. Bot. 76: 1569-1582.

Scheckler SE \& Galtier J. 2003. Tyloses and ecophysiology of the early carboniferous progymnosperm tree Protopitys buchiana. Ann. Bot. 91: 739-747.

Schmid R. 1965. The fine structure of pits in hardwoods. In: Côté WA(ed.), Cellular ultrastructure of woody plants: 291-304. Syracuse University Press, Syracuse.

Schmitt U \& Liese W. 1990. Wound reaction of the parenchyma in Betula. IAWA J. 11: 413-420.

Schmitt U \& Liese W. 1993. Response of xylem parenchyma by suberization in some hardwoods after mechanical injury. Trees 8: 23-30.

Schmitt U \& Liese W. 1994. Wound tyloses in Robinia pseudoacacia L. IAWA J. 15: 157-160.

Schmitt U, Richter HG \& Muche C. 1997. TEM study of wound-induced vessel occlusions in European ash (Fraxinus excelsior L.). IAWA J. 18: 401-404.

Shah JJ \& Babu AM. 1986. Vascular occlusions in the stem of Ailanthus excelsa Roxb. Ann. Bot. 57: 603-611.

Shibata N, Harada H \& Saiki H. 1982. Development and structure of traumatic tyloses in Quercus serrata Thunb. II. Developing process of the traumatic tylosis wall. Mokuzai Gakkaishi 28: $1-9$.

Shigo AL \& Marx H. 1977. CODIT: Compartmentalization of decay in trees. U.S. Dep. Agr. Inf. Bull. 405: 1-73.

Stevenson JF, Matthews MA, Greve LC, Labavitch JM \& Rost TL. 2004. Grapevine susceptibility to Pierce's disease II: progression of anatomical symptoms. Amer. J. Enol. Viticult. 55: 238-245.

Sun Q, Rost TL \& Matthews MA. 2008. Wound-induced vascular occlusions in Vitis vinifera (Vitaceae): Tyloses in summer and gels in winter. Amer. J. Bot. 95: 1498-1505.

Sun Q, Rost TL, Reid MS \& Matthews MA. 2007. Ethylene and not embolism is required for wound-induced tylose development in stems of grapevines. Plant Physiol. 145: 16291636.

Takahashi K \& Suzuki M. 2003. Dicotyledonous fossil wood flora and early evolution of wood characters in the Cretaceous of Hokkaido, Japan. IAWA J. 24: 269-309. 
Taylor AM, Gartner BL \& Morrell JJ. 2002. Heartwood formation and natural durability a review. Wood Fiber Sci. 34: 58-611.

Tomlinson PB, Horn JW \& Fisher JB. 2011. The anatomy of Palms - Arecaceae - Palmae. Oxford University Press, Oxford.

Tyree MT \& Zimmermann MH. 2002. Xylem structure and the ascent of sap. Springer, Berlin. van Bel AJ \& van der Schoot C. 1988. Primary function of the protective layer in contact cells: buffer against oscillations in hydrostatic pressure in the vessels? IAWA J. 9: 285-288.

van der Molen GE, Beckman CH \& Rodehorst E. 1987. The ultrastructure of tylose formation in resistant banana following inoculation with Fusarium oxysporum f. sp. cubense. Physiol. Mol. Plant Pathol. 31: 185-200.

Weiss FE. 1906. On the tyloses of Rachiopteris corrugata. New Phytol. 5: 82-85.

Wheeler EA. 2011. InsideWood - a web resource for hardwood anatomy. IAWA J. 32: 199-211.

Wheeler EA, Baas P \& Rodgers S. 2007. Variations in dicot wood anatomy: a global analysis based on the InsideWood database. IAWA J. 28: 229-258.

Wheeler EA \& Lehman TM. 2009. New late Cretaceous and Paleocene dicot woods of Big Bend National Park, Texas, and review of Cretaceous wood characteristics. IAWA J. 30: 293-318.

Williamson WC. 1876. On the organization of the fossil plants of the Coal-Measures. Part VII. Myelopteris, Psaronius, and Kaloxylon. Phil. Trans Royal Soc. London 166: 1-25.

Winckler E. 1854. Geschichte der Botanik. Literarische Anstalt (J. Riitten), Frankfurt.

Yu YB \& Yang SF. 1979. Auxin-induced ethylene production and its inhibition by aminoethoxyvinylglycine and cobalt ion. Plant Physiol. 64: 1074-1077.

Zimmermann MH. 1979. The discovery of tylose formation by a Viennese lady in 1845. IAWA Bull. 1979/2: 51-56.

Accepted: 22 February 2016 